\title{
Developing forage based rations for lactating buffaloes
}

\author{
MA Akbar \\ Department of Animal Nutrition, CCS Haryana Agricultural University Hisar, 125004 Haryana, India
}

Sorghum is a common forage in India but its crude protein content, and its intake by the buffaloes are low which could be overcome by mixing sorghum with legumes. An attempt was, therefore, made to study the effect of feeding sorghum-cowpea silage on nutrients utilization and milk production in Murrah buffaloes.

Twelve Murrah buffaloes were randomly divided into three groups of four in each, on the basis of their milk yield. In animals of group 1 (control), the nutrient requirements for maintenance and milk production were met by concentrate mixture and wheat straw. The buffaloes in group 2 were offered sorghumcowpea (2:1) silage to meet their maintenance requirements, and the production requirement was met by concentrate mixture. While the buffaloes in group 3 were offered sorghumcowpea (2:1) silage to meet their maintenance requirements plus nutrient required for $2 \mathrm{~kg}$ milk produced, the rest of the production requirements being met by the concentrate mixture. The nutrient requirements were as per the NRC recommendation (1990, NRC, NAS, Washington, DC). The concentrate mixture was offered to the buffaloes once in the morning at the time of milking. All the buffaloes were offered $1 \mathrm{~kg}$ of wheat bran mixed with 2 per cent mineral mixture over and above the rations for let down of milk.

After this experiment which lasted for 42 days, a digestion trial of 5 days collection period was conducted. The data for daily dry matter intake and milk yield were recorded. The fat and SNF contents were determined weekly. The samples of feed, feed refusals and faeces were analysed (1990, AOAC, Washington, DC) and statistical analyses were done following standard procedure.

The sorghum-cowpea silage contained 8.88 per cent crude protein which was considerably higher than the crude protein content (4 to 6.5 per cent) generally found in sorghum forage or its silage. The diets were almost isonitrogenous and isocaloric. All the animals maintained their body weights. The average voluntary DM intake per $100 \mathrm{~kg}$ body weight was $2.27,2.67$ and $2.67 \mathrm{~kg}$, the differences being statistically not significant. However, differences in digestibility of dry matter $(P<0.05)$ and crude protein $(P<0.01)$ were significant. The DCP and TDN content (\%) of the rations were $7.44,5.49$ and 5.34 and $57.30,50.89$ and 47.88 , for group, 1, 2 and 3 respectively.

The fat and SNF percentage in milk of three groups were $7.42,6.96$ and 7.23 , and 9.57, 9.58 and 9.53 per cent, respectively. The daily milk and FCM yield were 7.97, 8.13 and 8.38, and $12.06,11.17$ and $12.69 \mathrm{~kg}$, respectively, the difference being statistically not significant indicating that feeding of sorghum-cowpea silage did not alter the milk production and its composition.

The buffaloes fed silage prepared from sorghum and cowpea in the ratio of 2:1 could sustain $2 \mathrm{~kg}$ milk production even with lesser amount of concentrate mixture and one $\mathrm{kg}$ concentrate mixture could be replaced by 10 $\mathrm{kg}$ silage. Thus, feeding of sorghum-cowpea silage compared to concentrate based ration holds promise in bring down the cost of milk production. 